\title{
PRESENCE OF BIRCH BARK BEETLE (Scolytus ratzeburgi) IN CROATIA
}

\section{PRISUTNOST BREZOVOG POTKORNJAKA BJELIKARA (Scolytus ratzeburgi) U HRVATSKOJ}

\author{
Ivan LUKIĆ1 ${ }^{\text {, Željko ZGRABLIĆ2 }}$, Vlatka MIČETIĆ STANKOVIĆ ${ }^{3}$
}

\begin{abstract}
SUMMARY
Bark beetles are one of the most important groups of forest pests and in recent years several bark beetle species have significantly impacted two biogeographic regions in Croatia. The Birch bark beetle (Scolytus ratzeburgi) is the only Scolytus species known to infest birch (Betula spp.) and is a potential threat to birch trees in Croatia but its presence has not been recorded for over 100 years. Here we review historical records of this species and examine several forest stands of Silver birch (B. pendula). The last published record of Birch bark beetle was from 1913 and entomological collections from Croatia only have specimens from neighboring countries. Examination of Silver birch forest stands discovered five new locations of Birch bark beetle with signs of its attack. This species in Croatia has a low population density in forests and urban areas. Impacts of this species may be minimal, but research on this bark beetle should not be neglected since it represents valuable part of entomofauna in Croatia. Further research in Croatia should target fungal relationships with this species in order to determine whether the bark beetle spreads tree pathogenic fungi. Assessment of possible long-term mortality trends across the southern range edge of Silver birch and the presence of the Birch bark beetle merits further attention.
\end{abstract}

KEY WORDS: Betula pendula, native species, Scolytinae

\section{INTRODUCTION}

\section{UVOD}

Bark beetles (Coleoptera: Curculionidae: Scolytinae) are one of the most important groups of forest pests primarily due to their ability to kill large numbers of trees (Kurtz et al., 2008; Raffa et al., 2008; Cudmore et al., 2010). In recent years, several bark beetle species have significantly impacted two biogeographic regions of Croatia. In 2015, the European spruce bark beetle (Ips typographus L., 1758) together with the Six-toothed spruce bark beetle (Pityogenes chalcographus L., 1761) killed large numbers of European spruce (Picea abies (L.) H. Karst.) weakened by ice damage in the previous year in the Alpine region of Gorski Kotar
(Hrašovec, 2016). In 2017, the Mediterranean pine beetle (Orthotomicus erosus Wollaston, 1857) killed trees in the Marjan recreation forest (Split, Croatia) and also on other locations situated within the Mediterranean region, predominantly on Aleppo pine (Pinus halepensis Mill.) weakened by drought (Spaić, 1964; Pernek et al., 2019a; Pernek et al., 2019b).

The Birch bark beetle (Scolytus ratzeburgi Janson, 1859), is the only Scolytus species known to infest birch (Betula spp. L.) and is a potential threat to birch trees in Croatia. This species is one of the largest in the subfamily Scolytinae (4.0 $-6.5 \mathrm{~mm}$ ). The body is typically cylindrical with black and very finely dotted striped elytra. Males have thick chaetae

\footnotetext{
'Dr.sc. Ivan Lukić, Division for Forest Protection and Game Management, Croatian Forest Research Institute, 10450 Jastrebarsko, Croatia

${ }^{2}$ Dr.sc. Željko Zgrablić, Research Centre for Forest Ecosystem Goods and Services "Josip Ressel", Croatian Forest Research Institute, 52000 Pazin, Croatia

${ }^{3}$ Dr.sc. Vlatka Mičetić Stanković, Department of Zoology, Croatian Natural History Museum, 10000 Zagreb, Croatia
} 

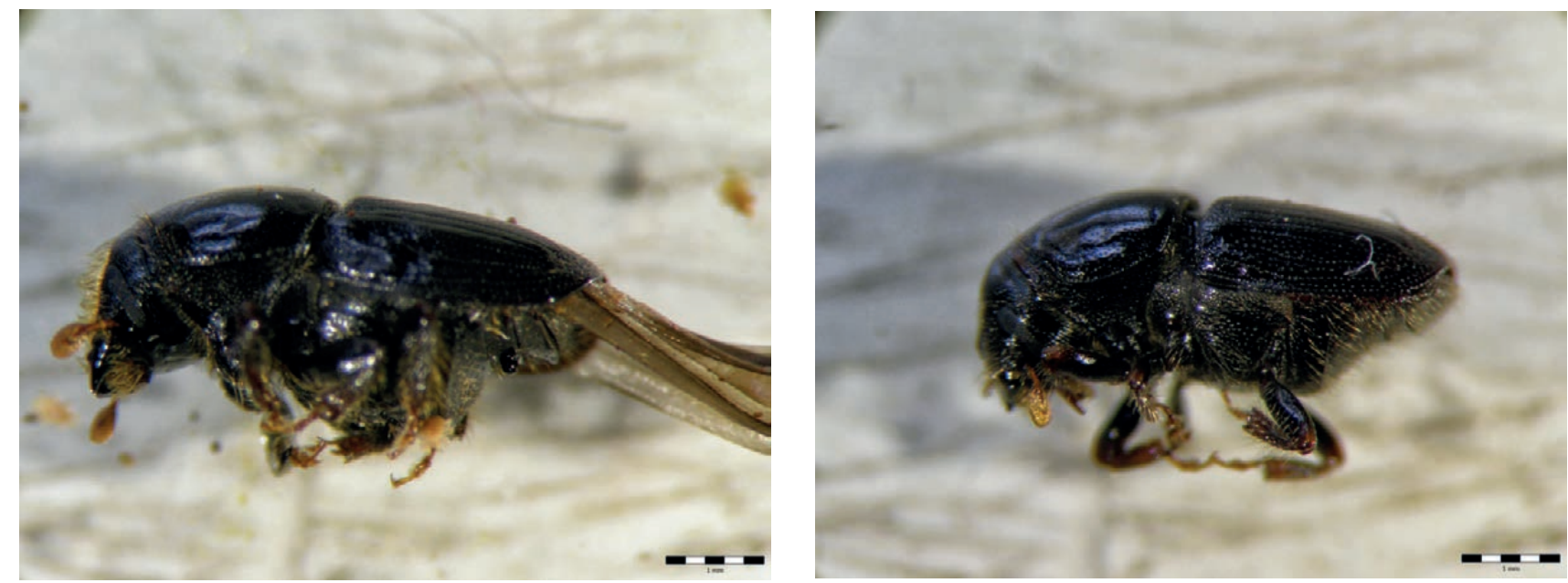

Figure 1 The Birch bark beetle (Scolytus ratzeburgi Janson, 1856): a) lateral view male; b) lateral view female Slika 1 Brezov potkornjak bjelikar (Scolytus ratzeburgi Janson, 1856): a) lateralni pogled mužjak; b) lateralni pogled ženka

on the frons and a specific button-shaped hump at the abdominal sternum three (Figure 1), which is one of the identification characteristics (Pfeffer, 1995). The gender of the bark beetle can be determined by sound as only the female stridulates (Scholz, 1905). Females produce sound using a gula-prosternal stridulation method (Barr, 1969; Dobai, 2017). Signs indicating the presence of the Birch bark bee- tle are holes on the bark located along the oviposition gallery (Figure 2). These holes may serve for mating locations (Trédl, 1915a; Trédl, 1915b; Munro, 1926; Kovačević, 1956) or for ventilation - humidity regulation (Melnikova, 1964). The holes, $2.0-2.5 \mathrm{~mm}$ in diameter, on the trunk are spaced along a vertical line up to $20 \mathrm{~cm}$ long (Trédl, 1915a; Trédl, 1915b; Melnikova, 1964; Zúbrik et al., 2013). Birch


Figure 2 The Birch bark beetle (Scolytus ratzeburgi Janson, 1856): a) ventilation holes along oviposition tunnel; b) typical gallery system with bark removed

Slika 2 The Birch bark beetle (Scolytus ratzeburgi Janson, 1856): a) zračne rupice uzduž materinskog hodnika; b) tipični galerijski sustav s uklonjenom korom 
bark beetles colonize dying or weakened trees (Zúbrik et al., 2013) although, they may also attack apparently healthy trees (Löyttyniemi, 1983; Linnakoski et al., 2009). The species is typically with one-year life cycle (Pfeffer, 1995) but may have two-year life cycle depending on the temperature of environment (Sieber \& Benz, 1985). Emergence, maturation feeding, mating, and egg deposition occur from May to June, depending on the location (Trédl, 1915a; Trédl, 1915b; Langhoffer, 1915; Kovačević, 1956). Little is known about their relationship with micro-organisms (Ring, 1977; Löyttyniemi, 1983; Sieber \& Benz, 1985) but recent studies of the Birch bark beetle have focused on their relationship with ophiostomatoid fungi (Linnakoski et al., 2008; Linnakoski et al., 2009; Jankowiak, 2011) and mites (Kiełczewski et al., 1983; Khaustov \& Magowski, 2003; Trach \& Kaustov, 2017).

The Birch bark beetle has been little studied and its presence in Croatia is unclear. Here, we (1) review historical records of this species (literature and available entomological collections) from Croatia and (2) examine forest stands with Silver birch (B. pendula Roth) to confirm the presence of the Birch bark beetle in Croatia.

\section{MATERIAL AND METHODS MATERIJALI I METODE}

Published records of the Birch bark beetle in Croatia were collected and specimens in museums and other institutions were checked. Museums in Croatia were the Croatian Natural History Museum (CNHM), Natural History Museum Rijeka (NHMR), Natural History Museum Split (NHMS), Varaždin City Museum (VCM) and National Museum Zadar (NMZ). Additionally, Hensch's entomological collection at the Faculty of Forestry, University of Zagreb was included in the study.

To determine the presence of Birch bark beetle in Croatia, Silver birch stands were examined throughout Croatia from 2016 to 2017. Logs were sampled at three localities through-

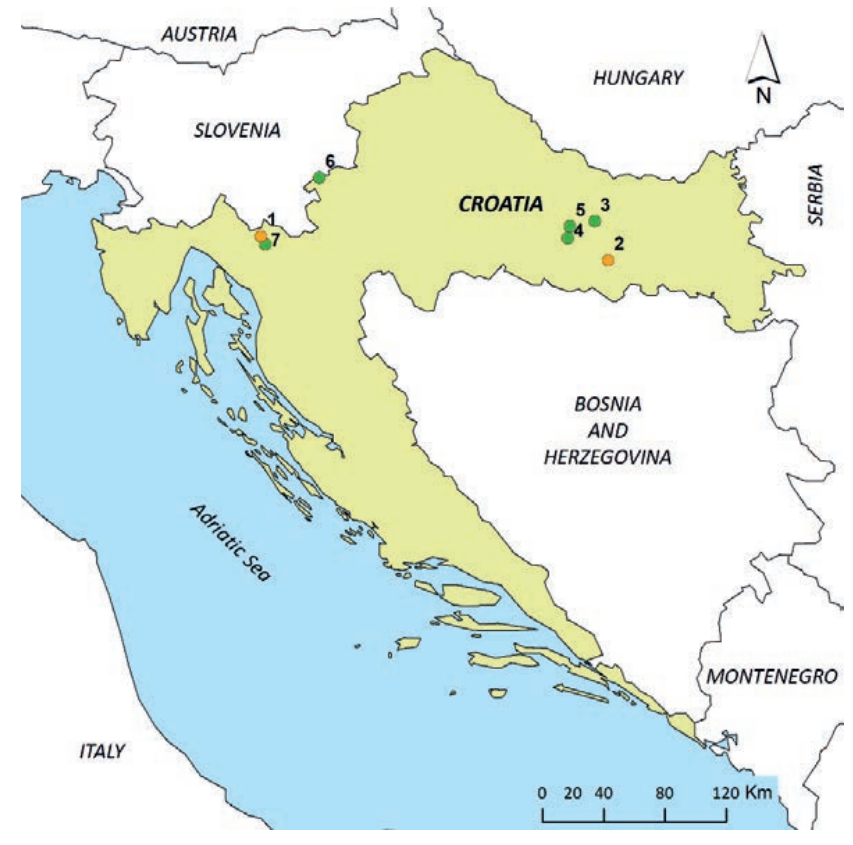

Figure 3 Historical (orange points: 1, 2) and current records (green points: $3-7$ ) of the Birch bark beetle (Scolytus ratzeburgi Janson, 1856) in Croatia.

Slika 3 Pronalasci brezovog potkornjaka bjelikara (Scolytus ratzeburgi Janson, 1856) u Hrvatskoj. Oznake lokaliteta: 1, 2: povijesni pronalasci, 3-7: trenutni pronalasci.

out Croatia and analyzed in the laboratory (Croatian Forest Research Institute). Geographical coordinates for each sampling site were collected using a GPS handheld device (Garmin GPSMAP ${ }^{\circ} 78$ s) and depicted on a map created with Esri ArcGIS 10.1 software. Illustrations were prepared using Adobe Illustrator CS6. Logs were kept at $20 \pm 1{ }^{\circ} \mathrm{C}, 65$ $\%$ r.h. and a photoperiod of 16h:8h (L:D). All emerging beetles were collected and identified to species, based on Pfeffer (1995) and Bense (1994).

Photos of killed trees were taken using a Canon EOS 550D, and photos of Birch bark beetle morphology traits were made with Leica WILD MZ-8 equipped with Olympus SP500 UZ (combined with Olympus QuickPHOTO CAMERA 2.2 microscopy imaging software).

Table 1 List of locations and years with records of the birch bark beetle (Scolytus ratzeburgi Janson, 1856) in Croatia.

Tablica 1 Popis lokacija i godina pronalaska brezovog potkornjaka bjelikara (Scolytus ratzeburgi Janson, 1856) u Hrvatskoj.

\begin{tabular}{|c|c|c|c|c|c|c|c|}
\hline Location & Label & Latitude & Longitude & $\begin{array}{l}\text { Altitude (m } \\
\text { a.s.l.) }\end{array}$ & $\begin{array}{l}\text { Number of logs } \\
\text { (n) }\end{array}$ & $\begin{array}{l}\text { Number of } \\
\text { beetles }(n)\end{array}$ & $\begin{array}{l}\text { Year of the } \\
\text { record }\end{array}$ \\
\hline Skrad & 1 & N 45.427800 & E 14.911100 & 670 & ND & ND & 1915 \\
\hline Duboka & 2 & N 45.388694 & E 17.975233 & 235 & ND & ND & 1906 \\
\hline Jankovac & 3 & N 45.521389 & E 17.699722 & 599 & 3 & 34 & 2016 \\
\hline Orljavac & 4 & N 45.424167 & E 17.475278 & 596 & ND & ND & 2016 \\
\hline Striježevica & 5 & N 45.491422 & E 17.491939 & 534 & 1 & 0 & 2016 \\
\hline Sošice & 6 & N 45.777406 & E 15.392628 & 855 & ND & ND & 2017 \\
\hline Ravna Gora & 7 & N 45.382794 & E 14.948177 & 893 & 5 & 21 & 2017 \\
\hline
\end{tabular}




\section{RESULTS}

\section{REZULTATI}

\section{Historical records of the Birch bark beetle in Croatia - Povijesni pronalasci brezovog potkornjaka bjelikara u Hrvatskoj}

The Birch bark beetle was first recorded in Croatia between 1891 and 1906 in Duboka close to Pleternica (Koča, 1900; Koča, 1906). An additional observation of the bark beetle was made in Skrad in 1913 (Trédl, 1915b; Langhoffer, 1915). Depoli (1940) reports the possible presence of the Birch bark beetle in Skrad in the 1930's, but detailed information regarding the impacts on forest stands or research conducted on the bark beetle is lacking.

None of the museum specimens of this bark beetle were collected from Croatia, they originate from neighboring countries. Therefore, 103 years have passed since this species was last recorded in Croatia. Specimens of the Birch bark beetle are in two collections held within CNHM: Spaić \& Pfeffer beetle collection (1. Wingelmüller, Butschowitz, Czech Republic, South Moravian Region; Inv. No 2251; 2. Württemberg (Württemberg), Germany; Inv. No 2252) and in the Novak insect collection (CNHM) a specimen of the Birch bark beetle exists, but without the description of the location, only with the name of the collector - "Josef Klimesch". In Hensch's entomological collection at the Faculty of Forestry, University of Zagreb specimens of the Birch bark beetle originate from Vojvodina, Serbia ("Ruma, Slavonija").

\section{Current records of the Birch bark beetle in Croatia - Trenutni pronalasci brezovog potkornjaka bjelikara u Hrvatskoj}

Silver birch tree logs (containing Birch bark beetles) were collected in Striježevica, on November $23^{\text {rd }}, 2016$. On November $24^{\text {th }}, 2016 \operatorname{logs}$ were collected from Jankovac and July $3^{\text {rd }}, 2017$ logs were collected from Ravna Gora. At two other locations (Orljavac and Sošice) signs of attack from Birch bark beetles were observed (Figure 3, Table 1). In total, 55 specimens (18 males, 37 females) were collected from field collected Silver birch logs. Also, specimens of the longhorn beetle Saperda scalaris L. (1758) (Coleoptera: Cerambycide) and an insect parasitoid Dendrosoter protuberans Nees (1834) (Hymenoptera: Braconidae) emerged from logs.

\section{DISCUSSION AND CONCLUSIONS RASPRAVA I ZAKLJUČCI}

Faunistic studies of bark beetles in Estonia, Finland, Russia (Voolma et al., 2004, Mandelshtam \& Khairetdinov, 2017) and Slovakia (Kollár et al., 2009) regularly record the presence of Birch bark beetle. Although the Birch bark beetle is distributed throughout Europe, Siberia, Korea, Japan and
China (Pfeffer, 1995; Vigna Taglianti et al., 1999; AlonsoZarazaga et al., 2016) it is rarely recorded in Croatia. The primary reason for few recorded occurrences in Croatia is that Silver birch is minor component of forest stands with a wood stock of only $0.10 \%$ and of little economic importance (Hrvatske šume d.o.o., 2017), which relates to southern edge of its distribution area in Europe (Kovačić \& Nikolić, 2005; Hynynen et al., 2009). Climate change effects on Silver birch have been researched in Finland (BricenoElizondo et al., 2006; Garcia-Gonzalo et al., 2007), and found that this tree species may increase in abundance at its northern range. This tree species will likely suffer and decline in abundance at its southern ranges as temperatures increase, but what will happen in Croatia requires further research. This bark beetle is the only Scolytus species to colonize and kill birch (Linnakoski et al., 2009). Throughout its range, the Birch bark beetle colonizes a number of birch species: B. pubescens (Ehrh.), B. pendula (Roth), B. raddeana (Trautv.), B. dahurica (Pall.), B. ermanii (Cham.), B. platyphylla (Sukatschev) and B. costata (Trautv.) (Pfeffer, 1995; Zúbrik et al., 2013). Since the last known record in Croatia was before 103 years ago (Trédl, 1915b; Langhoffer, 1915), we can conclude that this species in Croatia has a low population density in forests, although Silver birch trees can also be found in city parks and private gardens (Karavla, 2006), where so far the Birch bark beetle has gone unnoticed.

Impacts of this beetle may be minimal (Linnakoski et al., 2008; Linnakoski et al., 2009) but research on this bark beetle should not be neglected since it represents valuable part of entomofauna in Croatia. Research about the Birch bark beetle in other regions and their relationship with ophiostomatoid fungi have so far confirmed significant connection with the tree fungus Ophiostoma karelicum (Linnakoski et al., 2008; Linnakoski et al., 2009; Jankowiak, 2011). According to Linnakoski et al. (2008; 2009,) Ophiostoma karelicum pathogenic role combined with Birch bark beetle remains unclear. Similar bark beetle-fungal associations, but with far more visible impact on forest stands, can be seen with Dutch elm disease (pathogen Ophiostoma novoulmi) which is also transferred by Scolytus bark beetles (Moser et al., 2010) and Sudden wilt disease in Mango (pathogen Ceratocystis manginecans) transmitted by the bark beetle Hypocryphalus mangifera Stebbing (1914) (Al Adawi et al., 2012).

Further research about Birch bark beetle in Croatia should target fungal relationships in order to see which species of ophiostomatoid fungi are present and possibly to clarify its role on the southern edge of Silver birch distribution area. Phoretic mites also play an important role in bark beetle ecology and interactions between bark beetles, phoretic mites and ophiostomatoid fungi range from mutualism, commensalism to antagonism (Klepzig et al., 2001; Hofstetter et al., 2006, Moser et al., 2010). Phoretic mites are 
commonly associated with Birch bark beetle (e.g., Tarsonemus and Proctolaelaps mites; Khaustov \& Magowski, 2003; Trach \& Kaustov, 2017) and may play a role in the dispersal and introduction of fungal plant pathogens.

Although Silver birch is of minimal economic importance in Croatia, warming temperatures may lead to a rapid decline in the growth and a consequent retreat of the species from this region. Assessment of possible long-term mortality trends across the southern range edge of Silver birch and the presence of the Birch bark beetle merits further attention.

\section{ACKNOWLEDGMENTS}

\section{ZAHVALE}

The authors thank colleagues Antica Bregović (VCM), Bože Kokan (NHMS), Dr. Snježana Vujčić-Karlo (NMZ), and Doc. Milivoj Franjević (Faculty of Forestry, University of Zagreb) for help with the revision of beetle collections and Prof. Richard Hofstetter (School of Forestry, College of the Environment, Forestry and Natural Sciences, Northern Arizona University) for the help with unreachable references. In addition, authors thank colleagues from the Division of Forest Protection and Game Management (Croatian Forest Research Institute) for help with field and laboratory work and to the Ministry of Agriculture of the Republic of Croatia for the support through Diagnosis and Prognosis Service (IPP).

\section{REFERENCES}

\section{LITERATURA}

- Al Adawi, A.O., R.M. Al Jabri, M.L. Deadman, I. Barnes, B. Wingfield, M.J. Wingfield, 2012: The mango sudden decline pathogen, Ceratocystis manginecans, is vectored by Hypocryphalus mangiferae (Coleoptera: Scolytinae) in Oman, Eur J Plant Pathol, 135: 243-251

- Alonso-Zarazaga, M.A., R. Caldara, A. Machado, N. Maughan, J. Pelletier, H. Pierotti, L. Ren, A. Sforzi, H. Silfverberg, J. Skuhrovec, 2016: Addenda and Corrigenda to the Catalogue of Palaearctic Coleoptera, volumes 7 and 8 (CURCULIONOIDEA), Graellsia, 72 (1): 1-42

- Barr, B.A., 1969: Sound production in Scolytidae (Coleoptera) with emphasis on the genus Ips. Can Entomol, 101 (6): 636-672

- Bense, U., 1994: Longhorn Beetles: Illustrated Key to the Cerambycidae of Europe, Verlag Josef Margraf, 513 p., Weikersheim

- Cudmore, T.J., N. Björklund, A.L. Carroll, B.S. Lindgren, 2010: Climate change and range expansion of an aggressive bark beetle: evidence of higher beetle reproduction in naïve host tree populations, J Appl Ecol, 47 (5): 1036-1043

- Depoli, G., 1940: I coleotteri della Liburnia. Parte VII: Rhynchopora e supplement all parta VI Phytophaga, Società di Studi Fiumani, 15-16: 211-338

- Dobai, A., 2017: “Can you hear me?” Investigating the acoustic communication signals and receptor organs of bark beetles, Doctoral dissertation, Carleton University Ottawa
- Hofstetter R.W., J.T. Cronin, K.D. Klepzig, J.C. Moser, M.P. Ayres, 2006: Antagonisms, mutualisms and commensalisms affect outbreak dynamics of the southern pine beetle, Oecologia, 147 (4): 679-691

- Hrašovec, B., 2016: Overview of the situation of bark beetle management in Croatia (relating to the ice storm event on January $1^{\text {st }}-$ February $\left.6^{\text {th }}, 2014\right)$, Meeting regarding challenges in bark beetle management after ice storms - GOZDIS, Ljubljana

- Hrvatske šume d.o.o., 2017: Šumskogospodarsko područje Republike Hrvatske - Šumskogospodarska osnova - Uređajni zapisnik, Važnost: 01. 01. 2016. - 31. 12. 2025

- Hynynen, J., P. Niemistö, A. Viherä-Aarnio, A. Brunner, S. Hein, P. Velling, 2009: Silviculture of birch (Betula pendula Roth and Betula pubescens Ehrh.) in northern Europe, Forestry, 83 (1): 103-119

- Jankowiak, R., 2011: First report of Ophiostoma karelicum from birch stands in Poland, Phytopathologia, 59: 55-58

- Karavla, J. 2006: Dendrološke karakteristike zelene potkove grada Zagreba s prijedlogom obnove njezinoga istočnog dijela, Sum list, 1-2: 31-40

- Khaustov, A.A., W.L. Magowski, 2003: New data on tarsonemid mites (Acari: Tarsonemidae) associated with subcortical beetles (Coleoptera) in Ukraine and Russia, Acarina, 11: 241-245

- Kiełczewski, B., J.C. Moser, J. Winiewski, 1983: Surveying the acarofauna associated with Polish Scolytidae, Bulletin de la Société des amis des sciences et des lettres de Poznań, Série D, Vol. 22: $151-161$

- Klepzig K.D., J.C. Moser, M.J. Lombardero, R.W. Hofstetter, M.P. Ayres, 2001: Symbiosis and competition: complex interactions among beetles, fungi, and mites, Symbiosis, 30: 83-96

- Koča, GJ., 1900: Prilog fauni gore Papuka i njegove okoline, Glasnik hrvatskoga naravoslovnoga društva, XII (1 - 3): 100-134

- Koča, GJ., 1906: Popis tvrdokrilaca (kornjaša) Vinkovačke okoline. (Enumeratio coleopterorum circa Vinkovce inventorum), Glasnik hrvatskoga naravoslovnoga društva, XVII. - druga polovina: 119-212

- Kollár, J., P. Hrubík, S. Tkáčová, 2009: Monitoring of Harmful Insect Species in Urban Conditions in Selected Model Areas of Slovakia, Plant Protect Sci, 45 (3): 119-124

- Kovačević, Ž., 1956: Familija: Scolytidae - Potkornjaci. In: Kovačević, Ž. (ed), Primijenjena entomologija, III. knjiga, Šumski štetnici. Poljoprivredni nakladni zavod. p. 223-313

- Kovačić, S., T. Nikolić, 2005: Relations between Betula pendula Roth (Betulaceae) leaf morphology and environmental factors in five regions of Croatia, Acta Biol Cracov Bot, 47 (2): 7-13

- Kurtz, W.A., C.C. Dymond, G. Stinson, G.J. Rampley, E.T. Neilson, A.L. Carroll, T. Ebata, L. Safranyik, 2008: Mountain pine beetle and forest carbon feedback to climate change, Nature, 452 : 987-990

- Linnakoski, R., Z.W. de Beer, M. Rousi, P. Niemelä, A. Pappinen, M.J. Wingfield, 2008: Fungi, including Ophiostoma karelicum sp. nov., associated with Scolytus ratzeburgi infesting birch in Finland and Russia, Mycol Res, 112 (12): 1475-1488

- Linnakoski R., Z.W. de Beer, M. Rousi, H. Solheim, M.J. Wingfield, 2009: Ophiostoma denticiliatum sp. nov. and other Ophiostoma species associated with the birch bark beetle in southern Norway, Persoonia, 23: 9-15

- Löyttyniemi, K., 1983: Flight periods of some birch timber insects, Silva Fenn, 17 (4): 419-422

- Mandelshtam, M.Y., R.R. Khairetdinov, 2017: Additions to the check list of bark beetles (Coleoptera, Curculionidae: Scolytinae) 
from Leningrad Province, Russia, Entomological Review, 97 (7): 893-899

- Melnikova, N.I., 1964: Biological significance of the air holes in egg tunnels of Scolytus ratzeburgi Jans. (Coleoptera, Ipidae), Entomological Revue, 43: 16-23

- Moser, J.C., H. Konrad, S.R. Blomquist, T. Kirisits, 2010: Do mites phoretic on elm bark beetles contribute to the transmission of Dutch elm disease?, Naturwissenschaften, 97 (2): 219-227

- Munro, J.W., 1926: British bark beetles, Forestry Commission Bulletin, (8): 1-77

- Pernek, M., N. Lacković I., Lukić, N. Zorić, D. Matošević, 2019: Outbreak of Orthotomicus erosus (Coleoptera, Curculionidae) on Aleppo Pine in the Mediterranean Region in Croatia, SEEFOR 10 (1): 19-27

- Pernek, M., N. Zorić, M. Matek, I. Lukić, S. Novak Agbaba, B. Liović, I. Mihaljević, N. Lacković, 2019: Sušenje alepskog bora i gradacija potkornjaka Orthotomicus erosus u park šumi Marjan, Radovi (Hrvat. Šumar. inst.) 46 (1): 1-18

- Pfeffer, A., 1995: Zentral- und westpaläarktische Borken- und Kernkäfer. Pro Entomologia, c/o Naturhistorisches Museum, 309 p., Basel

- Raffa, K.F., B.H. Aukema, B.J. Bentz, A.L. Carroll, J.A. Hicke, M.G. Turner, W.H. Romme, 2008: Cross-scale drivers of natural disturbances prone to anthropogenic amplification: the dynamics of bark beetle eruptions, Bioscience, 58 (6): 501-517

- Ring, R.A., 1977: Cold-hardiness of the bark beetle, Scolytus ratzeburgi Jans. (Col., Scolytidae), Nor J Entomol, 24: 125-136

- Scholz, R. 1905: Der Tonapparat von Scolytus Ratzeburgi Janson und die Entwicklung des Tonapparates bei einigen Scolytus - Arten. (Col.), Insektenbörse, 22: 143-144.
- Sieber, R., G. Benz, 1985: The diapause of the birch engraver, Scolytus ratzeburgi Janson (Col., Scolytidae), ist termination by chilling, and manipulation with ecdysterone, Mitt Schweiz Entomol Ges, 58: 193-198

- Spaić, I., 1964: Pokusi suzbijanja potkornjaka na alepskom boru metodom prstenovanja, Šum list, 5-6: 226-236

- Trach, V.A., A.A. Khaustov, 2017: Mites of the genus Proctolaelaps Berlese, 1923 (Acari: Mesostigmata: Melicharidae) associated with bark beetles in Asian Russia, Acarina, 25 (2): 151-163

- Trédl, R., 1915a: Aus dem Leben des Birkensplintkäfers, Scolytus Ratzeburgi Jans. (Eccoptogaster destructor Ratz.), Entomologische Blätter, 4-6: 97-102

- Trédl, R., 1915b: Aus dem Leben des Birkensplintkäfers, Scolytus Ratzeburgi Jans. (Eccoptogaster destructor Ratz.), Entomologische Blätter, 7-9: 146-154

- Vigna Taglianti, A., P.A. Audisio, M. Biondi, M.A. Bologna, G.M. Carpaneto, A. De Biase, S. Fattorini, E. Piattella, R. Sindaco, A. Venchi, M. Zapparoli, 1999: A proposal for a chorotype classification of the Near East fauna, in the framework of the Western Palearctic region, Biogeographia, 20: 31-59

- Voolma, K., M.J. Mandelshtam, A.N. Shcherbakov, E.B. Yakovlev, H. Õnap, I. Süda, B.G. Popovichev, T.V. Sharapa, T.V. Galasjeva, R.R. Khairetdinov, V.A. Lipatkin, E.G. Mozolevskaya, 2004: Distribution and spread of bark beetles (Coleoptera: Scolytidae) around the Gulf of Finland: a comparative study with notes on rare species of Estonia, Finland and North-Western Russia, Entomol Fennica, 15 (4): 198-210

- Zúbrik, M., A. Kunca, G. Csóka, 2013: Insects and Diseases Damaging Trees and Shrubs of Europe, N.A.P. Éditions, 535 p.

\section{SAŽETAK}

Potkornjaci su jedna od najvažnijih skupina šumskih štetnika, a u posljednjih nekoliko godina zabilježene su štete od istih u dvije biogeografske regije Hrvatske. Smrekov pisar (Ips typographus) na području alpinske i mediteranski potkornjak (Orthotomicus erosus) na području mediteranske regije ukazali su na njihovu važnost. Brezov potkornjak bjelikar (Scolytus ratzeburgi) je jedina vrsta iz roda Scolytus kojoj su domaćini vrste iz roda Betula spp. te kao takva može predstavljati potencijalnu opasnost u Hrvatskoj. Prisutnost ove vrste je vidljiva po rupicama na kori, ispod kojih se nalazi materinski hodnik (Slika 2), a mužjak i ženka se razlikuju po količini dlaka na prednjem dijelu glave te po izbočini na zadku (Slika 1). Kako bi utvrdili prisutnost brezovog potkornjaka bjelikara na području Hrvatske, u ovom radu je napravljen pregled povijesnih zapisa (entomološke zbirke i literatura) i sastojina obične breze (B. pendula). Na terenu su sakupljeni uzorci (trupčići) na kojima je uočena prisutnost brezovog potkornjaka bjelikara te je napravljena laboratorijska analiza. Pregledom literature utvrđen je posljednji zabilježeni pronalazak brezovog potkornjaka bjelikara od prije više od 100 godina (1913. godina), a primjerci u entomološkim zbirkama potječu iz susjednih zemalja. Terenski pregled sastojina obične breze utvrdio je pet novih lokacija na kojima je vidljiva prisutnost brezovog potkornjaka bjelikara (Slika 3; Tablica 1). Gustoća populacije ove vrste u šumskim i urbanim područjima Hrvatske je niska, ali bez obzira na tu činjenicu brezov potkornjak bjelikar predstavlja važan dio entomofaune Hrvatske. Nastavak istraživanja trebao bi razjasniti povezanost brezovog potkornjaka bjelikara s patogenim gljivičnim bolestima i foretičkim grinjama s obzirom na moguće promjene na južnom rubu područja rasprostranjenja obične breze.

KLJUČNE RIJEČI: Betula pendula, autohtona vrsta, Scolytinae 